DOI https://doi.org/10.18551/rjoas.2020-11.14

\title{
INSTITUTIONAL ANALYSIS AND MARKET STRUCTURE OF CLIMBING PERCH WITH BIOFLOC CULTURE SYSTEM
}

\author{
Lilimantik Emmy, Ahmadi* \\ Faculty of Marine and Fisheries, Lambung Mangkurat University, Indonesia \\ *E-mail: ahmadi@ulm.ac.id
}

\begin{abstract}
The field research was carried out to analyze institutional marketing and market structure of Climbing perch with bioflock culture system by describing its marketing channel, marketing margin and farmer's share. Direct obervations were made by visiting fish farmer groups and some local markets in both South and Central Kalimantan Provinces. The respondents of fish farmers were selected by sensus method, while the wholesalers and retailers were determined by snowball sampling method. They were interviewed with a combination of structured and unstructured questions. The results showed that there was only one marketing channel: fish farmers $\rightarrow$ wholesalers $\rightarrow$ retailers $\rightarrow$ end consumers. The fish prices at fish farmers or wholesalers and retailers level were 60,200 and 70,767 IDR/kg, respectively. The proportion of marketing margin for wholesalers and retailers was $45 \%$ and $55 \%$, where wholesalers paid marketing cost $8 \%$ higher than retailers did. Farmer's share obtained was $85 \%$, meant that marketing system at fish farmer level was efficient. Regression analysis showed that the market was not perfectly integrated $(\beta<1)$ leading to the market structure to be oligopolistic. The reasons behind this including recommendations to improve marketing performance in the near future were also discussed.
\end{abstract}

\section{KEY WORDS}

Bioflock, farmer's share, marketing channel, marketing margin, market structure.

Indonesia is now the second largest global fish producer over the world. The fishery sector contributes about $8 \%$ of national gross domestic product. It was estimated that more than 11 million people are working in this sector as fishermen (8.69\%), fish farmers $(35.06 \%)$, fish processors and fish marketers $(55.84 \%)$, and salt farmers $(0.41 \%)$. It is recognized that consuming fish is very good for health as fish provides essential amino acid, calcium, phosphorus, iron, zinc, copper, vitamins (Tilami and Sampels, 2017). Fish consumption increases from $47.34 \mathrm{~kg}$ to $50.69 \mathrm{~kg}$ per capita per year. Fish arranges for $19.50 \%$ of protein and $2.27 \%$ of lipid (Ahmed et al., 2012). Nowadays, perception of consumer preferences for consuming fish is highly appreciated (Esilaba et al., 2017). Fish consumption preferences are affected by individuals' socio-economic characteristics (Can et al., 2015).

Fish marketing is a crucial factor to success for producers (i.e. fishermen, fish farmers, fish processors) and traders to earn the profit since fish being a highly perishable commodity needs immediately processed or sold after harvest (Rokeya et al., 1997; Lilimantik, 2011; Husen, 2019). It spoils soon after death due to microbial actions, which result in disagreeable taste, smell and texture thereby reducing consumer acceptability (Garrow and James, 1994). Meanwhile the fish price fluctuates much depend on the season, the quantity and quality of fish, the type and size of fish, freshness, supply and demand, market structure, market distance, and also long-short of marketing channels (Aswathy and Abdu Samad, 2013; Begum et al., 2014; Rahman et al., 2019). All fish marketed here are in the form of fresh fish, live fish, frozen and smoked fish generated from fishing, aquaculture and fish processing. Nowadays, business transaction can be done through fish market, retail market, fishing port or even via internet order (Ahmed and Hossain, 2012). Basically the marketing system is the exchange activities associated with transferring property rights to commodities, physically purchasing and allocating resources, handling of products, disseminating information to participants, market intermediaries and institutional arrangements for facilitating these 
activities (Hussain et al., 2003; Hossain et al., 2015; Husen, 2019). Since many parties who involved in the marketing channels so that the marketing system is needed to be wellmanaged and integrated (Sathiadhas and Kanagam, 2000; Omar et al., 2014) in order to create the healthy and sustainable business environment.

For Kalimantan's people, Climbing perch (Anabas testudineus), known as "Papuyu", is favorably considered as one of commercially important freshwater fish species (Ahmadi, 2019). The fish are usually served as delicious food with high quality meat. The market demand for Climbing perch continuously increase from time to time, meanwhile the market supply is still low in quantity and most highly dependent on the wild catch. Aquaculture may provide a solution to overcome this problem. Biofloc system is recently developed for aquaculture to increase the fish production. With this method, it is expected that (1) the availability of fish in the market is no longer dependent on the season, (2) the price of fish is stable, and (3) the market demand will be able to be met. The price at the retail level will be the basis for determining the price to be paid to the wholesalers and ultimately to fish farmers and vice versa. The price received by fish farmers will determine how much volume of production they produce which is then sold to the wholesalers or retailers. If the price received is satisfactory, the production offered to the market will increase, and vice versa.

The fulfillment of consumer demand is inseparable from how the market system has been worked. Almost all marketing activities assist fish farmers in understanding consumer desires. When it is done effectively and efficiently, overall marketing can boost income of fish farmers and increase profits of traders, as well as increase consumer purchasing power.

To understand comprehensively about the marketing activities of biofloc-based culture system, it is necessary to analyze institutional and market structure for Climbing perch.

\section{MATERIALS AND METHODS OF RESEARCH}

Study sites. The research activities were started by visiting the fish farmer groups of Climbing perch with biofloc culture system in Banjarbaru and then moved into local fish markets located in Banjarbaru, Rantau, Pelaihari of South Kalimantan Province, and Kapuas District of Central Kalimantan, Indonesia. The sampling sites were shown in Figure 1.

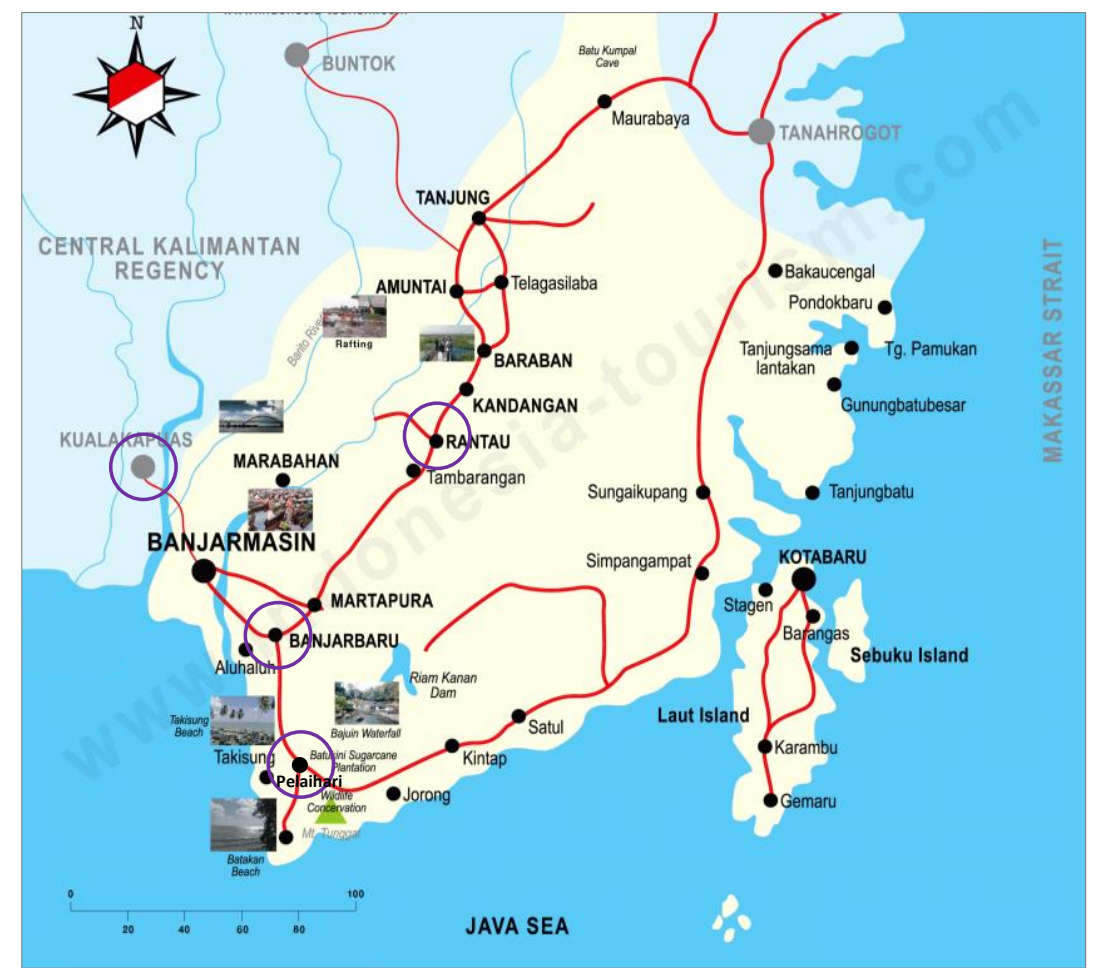

Figure 1 - The map showing the sampling sites (circles marks) of fish marketing for Climbing perch in South Kalimantan Province 
These locations are purposively selected to exemplify the marketing channels and distribution of Climbing perch at different levels. The fish markets are typically open in the early morning and then close by mid-afternoon. These fish markets are usually joined with the wet market that is also selling fresh meat, dried fish and other perishable goods such as vegetable and fruit. Fish markets are dominated by women. Official visits to the Fishery Services were also done to complement output of this research.

Characteristic of respondents. A total of 22 respondents who directly involved in marketing channels were selected comprising 5 fish farmers, 2 wholesalers and 15 retailers. The ages of respondents varied between 44-51 year olds with the duration of business experience ranged of 2-4 years.

Sampling method. The respondent of fish farmers were selected by sensus method, while the wholesalers and retailers were determined by snowball sampling method. Snowball sampling is a purposeful method of sampling in qualitative research (Naderifar et al., 2017). It is useful for identifying, selecting and taking samples in a continuous network or chain of relationships. The respondents were interviewed with a combination of structured and unstructured questions. The deep interview was undertaken to get overview and reliable information on the existing fish distribution, marketing channels, marketing systems, and also constraints being faced.

Marketing channel. The marketing channels of Climbing perch were analyzed using a descriptive method by investigating each marketing institution involved and its channels from fish farmers to the end consumer.

Marketing margin. Marketing margin is the difference between the prices at the end consumer and at the fish farmer level. It can be simply expressed as (Flowra et al., 2012):

$$
\mathrm{MM}=\mathrm{Pr}-\mathrm{Pf}
$$

Marketing margin stated in IDR. It can also be stated in the percentage (Rahman et al., 2012):

$$
\text { Marketing margin }=(\text { Selling price }- \text { Purchase price }) / \text { Selling price } \times 100
$$

Farmer's Share. The farmer's share is the ratio of price received by the fish farmer to the price paid by the end consumer. It can be calculated using the following formula (Saravanapandeeswari and Vanitha, 2017):

$$
\mathrm{Fs}=\mathrm{Fp} / \mathrm{Cp} \times 100
$$

Where: Fs is farmer's share (\%), Fp is fish farmer's price (IDR/kg) and Cp is consumer's price (IDR/kg). According to Kohls and Downey (1985), if the portion of the price received by fish farmer is greater than $50 \%$, then the marketing system can be said to be efficient. $A$ farmer's share will increase if the marketing margin is kept to a minimum. The level of farmer's share is influenced by prices at the consumer level.

Market Structure. Market structure is the characteristics of a market that impact the behavior and results of the organizations working in that market. It can be characterized based on the competition levels and the nature of the markets. Basically it provides a starting point for assessing economic environments in business. Market integration analysis can be used to determine market structure by seeing to what extent the price formation of a commodity at one level of a marketing agency is influenced by prices at the level of other marketing agencies. The assumption in market integration is that if the price of other factors is fixed, then the prices at both the producer and consumer levels are linear. The equation model used is as follows:

$$
\begin{aligned}
& \mathrm{Pfi}=\alpha+\beta \operatorname{Pri}+\mathrm{ei} \\
& \beta=\frac{\sum \operatorname{PriPfi}-\left(\sum \operatorname{Pri}^{2} \sum \mathrm{Pfi}^{2} / \mathrm{n}\right.}{\left(\sum \operatorname{Pri}^{2}-\Sigma \mathrm{Pfi}^{2} / \mathrm{n}\right)\left(\sum \mathrm{Pfi}^{2}-\Sigma \mathrm{Pri}^{2} / \mathrm{n}\right)}
\end{aligned}
$$


Where: $\mathrm{Pfi}=$ prices at the producer level, $\mathrm{Pri}=$ prices at the retail level, $\beta_{0}=$ Intersept, $\beta_{\mathrm{i}}=$ Parameter and ei $=$ error term.

Assessment criteria:

- If $\beta<1$, it means that the market structure is monopsony or oligopsony. An increase in the price of one unit at the retailer level is followed by an increase in the price of less than one unit at the fish farmer level. Monopsony refers to a market with a single buyer, while a oligopsony is a market dominated by a few large buyers.

- If $\beta=1$, it means that the market structure is perfect competition. An increase in the price of one unit at the retailer level is followed by an increase in the price of one unit at the fish farmer level. In other words, the formation of inter-market price is more integrated with the unit.

- If $\beta>1$, it means that the market structure is monopoly or oligopoly. An increase in the price of one unit at the retailer level is followed by an increase in the price of greater than one unit at the fish farmer level. Monopoly consist of a market with a single seller, while a oligopoly is a market dominated by a few large sellers.

The data were tabulated and analyzed using conventional statistical tools of Microsoft Excel 2010, then presented in textual, charts and tabular forms.

\section{RESULTS AND DISCUSSION}

Fish farmers were able to produce $60-240 \mathrm{~kg}$ of fish for 8 months of culture period. The sizes of fish varied from 10 to $12 \mathrm{~cm}$ total length and 38 to $45 \mathrm{~g}$ weight. The selling price at the fish farmers ranged from 59,000 to 62,000 IDR/ $\mathrm{kg}$, while at the retailer level ranged from 70,000 to $72.000 \mathrm{IDR} / \mathrm{kg}$. When the average fish price was set at $60,500 \mathrm{IDR} / \mathrm{kg}$, the fish farmers received money about 3,630,000 to 14,520,000 IDR. Among variable cost, pellet and fish seed were main purchase account to be borne by the fish farmers $30-41 \%$. While for retailers and wholesalers, it counted for about 93-98\% allocated for buying the fish.

In line with population growth and economy improvement, it is predicted that the market demand of Climbing perch for next 5 years ranging from 1.5 to 2 tons per day. Biofloc-based culture system of Climbing perch could be the best solution to meet this demand. The bioflock technology in aquaculture system had been successfully applied for some commercial fish and shrimp species such as Nile tilapia (Nahar et al., 2015), crucian carp (Wang et al. 2015); Indian carp (Kamilya et al., 2017); African catfish (Ekasari et al., 2016), gourami (Rosmawati and Muarif, 2017); the green tiger shrimp (Megahed, 2010), Japanese tiger prawn (Zhao et al., 2012); Malaysian prawn (Perez-Fuentes et al., 2013), pink shrimp (Emerenciano et al., 2013), the pacific white shrimp (Da Silva et al., 2013), the giant tiger prawn (Anand et al., 2014) and most recently applied for Climbing perch and business has favorable prospect (Izmaniar et al., 2018).

Marketing channel pattern. In the investigated area, there was only one marketing channel pattern for Climbing perch with biofloc culture system as shown in Figure 2.

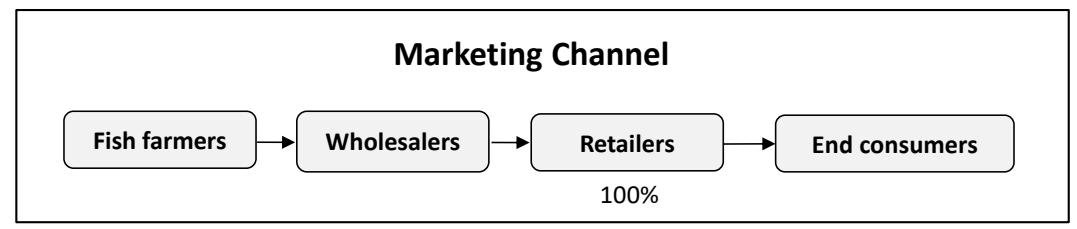

Figure 2 - Marketing channel pattern of Climbing perch from fish farmers to end consumers

Five fish farmers sold out the fish to the wholesalers and then distributed to the 15 retailers $(100 \%)$, and finally marketed to the end consumers. The basic reasons why the fish farmers preferred to sell the fish through the wholesallers are as follows: (1) they do not need to bear the transportation costs and other risks; (2) they do not need to sell the fish by themselves. The presence of wholesallers provide convenience for them during the process of harvesting, payment, transportation and distribution; (3) each fish farmer usually has own 
customer so that the sale transaction can work well; (4) the wholesallers also have the fixed customers (retailers) in some market areas so that the sales process can run quickly and timely. The retailers usually make the payment in cash; (5) there is a commitment and trust between fish farmers and wholesallers in term of payments, which is usually done by wholesallers after the fish have been sold out. In line with this, Kwon and Suh (2004) said that a partner's reputation in the market has a strong positive impact on the trust-building process. Success in business is determinable how the key players build a good market communication to generate a sustainable business.

Rabby et al. (2015) assumed that the producers and intermediaries could be more benefited financially, if efficient marketing was arranged properly. It is generally felt by the consumers that they have to pay higher price due to the involvement of too many intermediaries in the marketing channels. Thus, marketing system should be integrated.

Farmer's Share. From the available data, we estimated the value of farmer's share was $85 \%$ (Table 1), which was found to be higher than $50 \%$, indicating that fish marketing system here was considered to be economically efficient (Kohls and Downey, 1985). The large share of the price received by the fish farmers was closely related to the marketing system that has been established between the fish farmers and the wholesalers. It meant that the fish farmers had a good bargaining prower against the wholesalers in determining a reasonable price based on the size and quality of fish. Such bargaining interaction was also demonstrated by the aquafarmer's association in Thambikottai village of Tiruvarur District, India (Kumar et al., 2010). A decent income will increase the performance of fish farmers. Compared to other single-species from different geographical areas, our result being equal to the trout marketing in Kohgiloye and Boyer Ahmad Province of Iran (Shahi et al., 2012), but it was higher than European anchovy $(54 \%)$ or Atlantic horse mackerel $(60 \%)$ traded in Trabzon province (Dağtekin, 2010).

Table 1 - The share of the price recieved by the fish farmers

\begin{tabular}{llll}
\hline Description & $\begin{array}{l}\text { Price at fish farmers } \\
(\text { IDR/kg) }\end{array}$ & $\begin{array}{l}\text { Price at retailers } \\
(\text { IDR/kg) }\end{array}$ & $\begin{array}{l}\text { Farmer's share } \\
(\%)\end{array}$ \\
\hline Range & $59,000-62,000$ & $70,000-72,000$ & $84-86$ \\
Average & 60,200 & 70,767 & 85 \\
\hline
\end{tabular}

Marketing Margins. There was a variation in the fish prices at different marketing channels. The lowest fish price usually goes to the fish farmers and then increasingly at the wholesalers and terminates in the retailer leading to variation in the marketing margin (Table 2).

Table 2 - Market prices and marketing margin for Climbing perch at different levels of marketing channels

\begin{tabular}{llll}
\hline Level of marketing channel & Variable observed & IDR/Kg & Percentage (\%) \\
\hline Fish farmers & Selling price & 60,200 & \\
Wholesalers & Purchase price & 60,200 & 0.52 \\
& Marketing cost & 2,270 & 65,000 \\
& Selling price & 2,530 & 0.48 \\
& Profit & 4,800 & \\
Retailers & Marketing margin & 65,000 & \\
& Purchase price & 2,100 & 70,767 \\
& Marketing cost & 3,667 & 5,767 \\
\hline
\end{tabular}


Table 3 - Regression analysis of the prices at fish farmer and retailer levels

\begin{tabular}{ll}
\hline Variable function & Regression value \\
\hline$\alpha$ & 20.308 \\
$\beta$ & 0.529 \\
$\mathrm{R}^{2}$ & 0.908 \\
$\mathrm{r}$ & 0.953 \\
\hline
\end{tabular}

There was a price difference of $10.567 \mathrm{IDR} / \mathrm{kg}$ derived from the price recieved by fish farmers $(60,200 \mathrm{IDR} / \mathrm{kg}$ ) and the price paid by consumers (IDR 70,767 per $\mathrm{kg}$ ). The marketing margin values at wholesalers and retailers level were 4,800 and 5,767 IDR/Kg, which obtained from the sum of marketing cost and profits received, indicating that the marketing margin at the retailers was greater than wholesalers; this is because the marketing costs borne by wholesalers was greater than those paid by the retailers.

The total amount of marketing margin was 10,567 IDR consisted of (a) marketing costs paid by the wholesalers 2,270 IDR and the retailers 2,100 IDR; (b) the profits received by the wholesalers 2,530 IDR and the retailers 3,667 IDR. From this comparison, it was known that the distribution of profits was greater than that of marketing costs. This means that marketing from the side of intermediary traders can be said to be efficient.

Market structure. In market structure, the price at retail level will be the basis for determining the price to be paid to wholesalers and ultimately to producers and vice versa. Furthermore, the price received by producers will determine how much production volume will be served for wholesalers or retailers. The production offered to the market will increase if the price received is satisfactory and vice versa (Apituley et al., 2018). There are three main elements in the market structure, namely market share, market concentration and barrier to entry (Lelissa and Kuhil, 2018). According to Shepherd (1972), each market structure is somewhere in the range between monopoly (a high market share and entry barrier) and pure competition (low share and barriers). Market structure affects the ability of producers or traders to set prices. Producers or traders have no the power to form or influence prices in a perfect competitive market, all market participants act as price takers. However, the ability to influence prices arises when the market structure is imperfect, even producers / traders can act as price makers if the market structure is monopoly.

There was a strong correlation between the prices at the fish farmers (Pf) and the retailers $(\operatorname{Pr})$ level $(r=0.953)$. The determination coefficient $\left(R^{2}\right)$ values range was 0.908 indicating that more than $90 \%$ of price variability at the fish farmers was explained by the price at the retailers. The market structure of Climbing perch can be seen from its regression coefficient. A linear regression model can be written as $\mathrm{Pf}=20.308+0.529 \operatorname{Pr}$. The $\beta$ value obtained was 0.529 or not equal to one $(\beta<1)$, which implies that any increase in price of 1 IDR at retail level will be followed by an increase in price of 0.529 IDR at the fish farmers level. The market was not perfectly integrated leading to the market structure to be oligopolistic. This condition describes an inefficient marketing system. The increase in price for one unit at the consumer level was followed by an increase in price was less than one unit at the fish farmer level.

At least, there were four reasons behind the formation of oligopoly market structure of Climbing perch: (1) the distance between the two markets was relatively far, which impact on the high cost of transportation. It was more convenience for fish farmers to cooperate with the wholesalers to avoid uncertain risks. (2) Fish farmers already have own customers (wholesalers) so that the buying and selling transactions take place on the spot. (3) Fish farmers were highly dependent on the wholesalers in selling their fish; as a result the wholesalers have a big role in determining the price. (4) Retailers also have a close relationship with the wholesalers who guarantee the availability of fish production; besides that, the retailers did not need to pay marketing costs to buy the fish from fish farmers.

Recommedations are made to improve the current marketing performance of Climbing perch: (1) There is a need for partnerships with related agencies for aquaculture business development through training and counseling to expand the market share. (2) In order to have a fair profit share, the fish farmers should have accurate market information, especially 
about prices and bargaining position in the market. The use of mobile phone-based Marketing Information Services program should be familiarized. (3) The fish farmers are encouraged to be a member of aquafarmer's association or other business entity to strengthen their bargaining power.

\section{CONCLUSION}

There was only a single marketing channel for Climbing perch started from fish farmers through market intermediaris to the end consumers. The marketing margin of retailers was $20 \%$ higher than wholesalers. The market was not perfectly integrated and the market structure was oligopoly, indicating that the current marketing system should be improved.

\section{REFERENCES}

1. Ahmadi. 2019. Morphometric characteristic and growth patterns of Climbing perch (Anabas testudineus) from Sungai Batang River, Indonesia. International Journal of Hydrology, 3(4): 270-277.

2. Ahmed, S., Hossain, B. 2012. Marketing strategies for frozen fish exporters in Bangladesh. Journal of Arts, Science and Commerce, 3(3): 1-8.

3. Ahmed, S., Rahman, A.F.M.A., Mustafa, M.G., Hossain, M.B., Nahar, N. 2012. Nutrient composition of indigenous and exotic fishes and rainfed waterlogged paddy fields in Lakshmipur, Bangadesh. World Journal of Zoology, 7(2): 135-140.

4. Anand, P.S.S., Kohli, M.P.S., Kumar, S., Sundaray, J.K., Roy, S.D., Venkateshwarlu, G., Sinha, A. and Pailan, G.H. 2014. Effect of dietary supplementation of biofloc on growth performance and digestive enzyme activities in Penaeus monodon, Aquaculture, 418: 108-115.

5. Aswathy, N., Abdussamad, E.M. 2013. Price behavior and marketing efficiency of marine fish in Tuticorin, Tamil Nadu. Journal of Fisheries Economics and Development, 13(2): 29-35.

6. Apituley, Y.M.T.N., Lopulalan, Y., Salakory, R.A., Bawole, D. 2018. Market structure, conduct and performance of Scad (Decapterus russeli) in Kota Ambon. Jurnal Manajemen and Agribisnis. 15(3): 221-229.

7. Begum, R., Akter, T., Barman, P.P., Marine, S.S., Hossain, M.M. 2014. Potential for development of marine fish marketing systems in Chittagong District of Bangladesh. Journal of the Sylhet Agricultural University, 1(2): 247-252.

8. Can, M.F. Gunlu, A., Can, H. 2015. Fish consumption preferences and factors influencing it. Food Science and Technology (Campinas), 35(2): 339-346.

9. Da Silva, K.R., Wasielesky, W., Abreu, P.C. 2013. Nitrogen and phosphorus dynamics in the bioflock production of the pacific white shrimp, Litopenaeus vannamei. Journal of World Aquaculture Society, 44(1): 30-41.

10. Dağtekin, M. 2010. Fishery production and marketing structure in Trabzon (MSc Thesis). Çukurova University, Adana, Turkey.

11. Ekasari, J., Suprayudi, M.A., Wiyoto, W., Hazanah, R.F., Lenggara, G.S., Sulistiani, R. 2016. Bioflock technology application in African catfish fingerling production: the effects on the reproductive performance of broodstock and the quality of eggs and larvae. Aquaculture, 464: 349-356.

12. Emerenciano, M., Cuzon, G., Paredes, A., Gaxiola, G. 2013. Evaluation of bioflock technology in pink shrimp Farfantepenaeus duorarum culture: growth performance, water quality, microorganisms profile and proximate analysis of bioflock. Aquaculture International, 21(6): 1381-1394.

13. Esilaba, F.A., Moturi, W.N., Mokua, M.A. 2017. Urban consumer's fish preferences and the determinants influencing fish selection and consumption: Case study of Nakuru, Kenya. International Journal of Fisheries and Aquatic Studies, 5(3): 356-360.

14. Flowra, F.A., Bashar, A.H.M., Jahan, K.S.N., Samad, M.A., Islam, M.M. 2012. Fish marketing system and socio economic status of Aratdars in Natore and Rajshahi, Bangladesh. Journal of Our Nature, 10(1): 34-43. 
15. Garrow, J.S., James, W.P.T. 1994. Human nutrition and dietetics. London, UK: Churchill Livingstone.

16. Hossain, M.A., Abdulla-Al-Asif, Zafar, M.A., Hossain, M.T., Alam, M.S., Islam, M.A. 2015. Marketing of fish and fishery products in Dinajpur and livelihoods of the fish retailers. International Journal of Fisheries and Aquatic Studies, 3(1): 86-92.

17. Husen, M.A. 2019. Fish marketing system in Nepal: Present status and Future prospects. International Journal of Applied Science and Biotechnology, 7(1): 1-5.

18. Hussain, S.A., Badar, H., Khokhar, S.B. 2003. Market intermediaries and their marketing margins for Inland Fish - A case study of Lahore District. International Journal of Agriculture and Biology, 5(1): 73-76.

19. Izmaniar, H., Mahyudin, I., Agusliani, E., Ahmadi. 2018. The business prospect of Climbing perch fish farming with bioflock technology at De' Papuyu Farm Banjarbaru. International Journal of Environment, Agriculture and Biotechnology, 3(3): 1145-1153.

20. Kamilya, D., Debbarma, M., Pal, P., Kheti, B., Sarkar, S., Singh, S.T. 2017. Biofloc technology application in indoor culture of Labeo rohita (Hamilton, 1822) fingerlings: The effects on inorganic nitrogen control, growth and immunity. Chemosphere. 182: 8-14.

21. Kumar, B.G., Ravisankarb, T., Sureshc, R., Bhattad, R., Vimalab, D., Kumaranb, M., Mahalakshmib, P., Sivasakthi Devi, T. 2010. Lessons from innovative institutions in the marketing of fish and fishery products in India. Agricultural Economics Research Review, 23: 495-504.

22. Kwon, I.W.G., Suh, T. 2004. Factors affecting the level of trust and commitment in supply chain management. Journal of Supply Chain Management, 40(2): 4-14.

23. Lelissa, T.B., Kuhil, A.M. 2018. The structure conduct performance model and competing hypothesis - A review of literature. Research Journal of Finance and Accounting. 9(1): 76-89

24. Lilimantik, E. 2013. Spatial Equilibrium of Tilapia (Oreochromis niloticus bleeker) Market in South Borneo Province, Indonesia. European Journal of Business and Management Vol. 5 No. 5, 2013

25. Megahed, M. 2010. The effect of microbial biofloc on water quality, survival and growth of the green tiger shrimp (Penaeus semisulcatus) fed with different crude protein levels. Journal of Arab Aquaculture Society, 5(2): 119-142.

26. Naderifar, M., Goli, H., Ghaljaie, F. 2017. Snowball sampling: A purposeful method of sampling in qualitative research. Strides in Development of Medical Education, 14(3): e67670.

27. Nahar, A., Abu, M., Siddik, B., Rahman, M.M. 2015. Bioflock technology in aquaculture systems generates higher income in mono-sex Nile tilapia farming in Bangladesh. Advances in Biological Research, 9(4): 236-241.

28. Omar, M.I., Dewan, M.F., Janifa, U.A., Hoq, M.S. 2014. Analysis of spatial cointegration and marketing margin of Tilapia (Oreochromis niloticus) fish in some selected areas of Bangladesh. Journal of Economics and Sustainable Development, 5(7): 63-70.

29. Perez-Fuentes, A., Perez-Rostro, C.I., Hernandez-Vergara, M. 2013. Pond-reared Malaysian prawn Macrobrachium rosenbergii with the bioflock system. Aquaculture, 400401: 105-110.

30. Rabby, A.F., Hossain, M.A., Alam, M.T., Uddin, M.S., Dey, T. 2015. Status and economics of three Upazilla fish markets in Moulavibazar District in Bangladesh. Journal of the Sylhet Agricultural University, 2(1): 87-95.

31. Rahman, M.M., Hossain, M.A., Fatematuzzhura, Tasnoova, S., Ahamed, F., Hossain, M.Y. Ohtomi, J. 2012. Fresh fish marketing status in the Northwestern Bangladesh: Recommendations for Sustainable Management. Our Nature, 10(1): 128-136

32. Rahman, Ahmadi, Mahreda, E.S. 2019. Marketing channels of marine fish in Banjarmasin fishing port, Indonesia. International Journal of Fisheries and Aquatic Research, 4(3): 15-22.

33. Rokeya, J.A., Ahmed, S.S., Bhuiyan, A.S., Alam, M.S. 1997. Marketing system of native and exotic major carps of Rajshahi District. Bangladesh Journal of Fisheries, 20(1-2): 99103. 
34. Rosmawati, Muarif. 2017. Growth and feed efficiency of Gourami fish reared in Biofloc media with different $\mathrm{C} / \mathrm{N}$ Ratios. International Journal of Sciences: Basic and Applied Research. 36(6): 47-59.

35. Saravanapandeeswari, V., Vanitha, B. 2017. Producer's share in consumer Rupee in the marketing of Banana, Theni District. International Journal of Current Science Research, 3(7): 1311-1320.

36. Tilami, S.K., Sampels, S. 2017. Nutritional value of fish: lipids, proteins, vitamins, and minerals. Reviews in Fisheries Science and Aquaculture, 26(2): 243-253.

37. Sathiadhas, R., Kanagam, A. 2000. Distribution problems and marketing management of marine fisheries in India. In: Marine Fisheries Research and Management, Pillai, V.N. and Menon, N.G. (eds.). MFRI; Kochi, p. 858-875.

38. Shepherd, W. 1972. The elements of market structure. Review of Economics and Statistics, 54: 25-37.

39. Shahi, H.M., Zeratkish, Y., Foroughi, V. 2012. Factors affecting Trout marketing in Kohgiloye and Boyer Ahmad Province of Iran. Journal of Food Agriculture and Environment, 10(1): 248-250.

40. Wang, G., Yu, E., Xie, J., Yu, D., Li, Z., Luo, W., Qiu, L., Zheng, Z. 2015. Effect of C/N ratio on water quality in zero-water exchange tanks and the biofloc supplementation in feed on the growth performance of crucian carp, Carassius auratus. Aquaculture. 443: 98-104.

41. Zhao, P., Huang, J., Wang, X.H., Song, X.L., Yang, C.H., Zhang, X.G., Wang, G.C. 2012. The application of bioflocs technology in high-intensive, zero exchange farming systems of Marsupenaeus japonicus. Aquaculture, 354-355: 97-106. 